\title{
Beyond human capital explanations for the gender pay gap among executives: investigating board embeddedness effects on discrimination
}

\author{
Jana Oehmichen • Maximilian A. Sarry • \\ Michael Wolff
}

Received: 1 August 2013/Accepted: 10 February 2014/Published online: 19 July 2014

(C) The Author(s) 2014. This article is published with open access at Springerlink.com

\begin{abstract}
This paper examines the gender pay gap in top management teams and how it is affected by directors' embeddedness. We can reconfirm the result of previous studies that differences in managerial compensation between women and men exist, even after controlling for company properties and human capital attributes. Drawing on the language theory of discrimination, we then question how the embeddedness of directors - the actual deciders on executive compensation levels-affects the pay gap: embeddedness causing homophilous behavior resulting in a higher pay gap or directors using their network as knowledge source and decreasing the pay gap. We find evidence that knowledge effects outweigh potential homophily effects.
\end{abstract}

Keywords Gender pay gap · Management compensation · Language theory of discrimination - Network embeddedness · Women on management boards

JEL Classification $\mathrm{J} 31 \cdot \mathrm{M} 12 \cdot \mathrm{J} 16 \cdot \mathrm{G} 30$

Responsible editor: Thomas Hutzschenreuter (Management).

J. Oehmichen $(\bowtie) \cdot$ M. A. Sarry $\cdot$ M. Wolff

Institute of Management and Control, Georg-August-University Goettingen, Göttingen, Germany e-mail: jana.oehmichen@wiwi.uni-goettingen.de

M. A. Sarry

e-mail: maximilian.sarry@wiwi.uni-goettingen.de

M. Wolff

e-mail: michael.wolff@wiwi.uni-goettingen.de 


\section{Introduction}

Discrimination in organizations is a prominent topic for regulators as well as researchers. Previous research studies about discrimination focused on employees (Bielby and Baron 1986; Goldman et al. 2006), managers (Piderit and Ashford 2003; King et al. 2010), and board members (Hillman et al. 2002; Bilimoria and Piderit 1994). In addition to the direct discrimination that occurs when companies do not appoint adequate numbers of minorities (Singh and Vinnicombe 2004), the indirect discrimination via compensation differences is a frequently discussed phenomenon (Millsap and Taylor 1996). With respect to gender, research discovered a pay gap in the general work force (Blau and Kahn 2001, 2007) as well as among executives (Kulich et al. 2011; Renner et al. 2002; Bertrand and Hallock 2001). In most cases, researchers identified human capital attributes such as a generally lower level of education of females as well as women's lower work experience as reason for the gender pay gap (Blau and Kahn 2007).

Drawing on the language theory of discrimination (Lang 1986), our research provides further insights to explain the residual gap between the compensation levels of female and male executives that are not explained by human capital attributes. Existing studies with focus on the link between individual attributes and compensation missed to consider characteristics and preferences of the committee that is ultimately deciding on executive compensation packages-the board of directors. Based on the concept of differences in methods of speaking and listening of the language theory of discrimination (Lang 1986), transaction costs emerge from communication between a majority and a minority. Boards have two options to react to these proposed transaction costs that a company might incur due to a minority member among members of the majority-in our analysis a female among male executives. First, they might refrain from appointing female managers entirely. The elevated political and social pressure, however, detains companies from this form of direct discrimination in their hiring strategy. Board members might, therefore, decide in favor of the second possible reaction and pass along the proposed transaction costs to the female manager and consequently grant them a lower compensation, regardless of the woman's human capital. Thus, we control for aspects of human capital when examining the pay gap between female and male managers and ask in our research question whether the assessment of transaction costs that leads to this pay gap is influenced by network embeddedness of board members. We adopt two competing theoretical perspectives to examine embeddedness effects on discrimination: the possibility of homophily among economic elites (Shipilov et al. 2011; McPherson et al. 2001) and the resource function of board networks (Beckman and Haunschild 2002; Shropshire 2010; Hillman et al. 2007). On the one hand, board members become members of the economic elite via additional directorships (Useem 1982; Davis and Greve 1997; Westphal and Khanna 2003) and this societal class is still predominately male (Adams and Ferreira 2009; Huse et al. 2009; Hillman et al. 2007). Following the homophily among economic elites perception of board embeddedness, embedded boards assess transaction costs for communication and cooperation with the female minority as greater. Since they pass on these greater transaction costs to female managers, the gender pay gap 
increases. On the other hand, the network of additional directorships might serve a resource function (Haunschild and Beckman 1998; Shropshire 2010). Through learning opportunities on different boards and exposure to more diverse groups, the estimation of language barriers and accordingly the assessment of transaction costs is reduced. This leads to less discrimination and a diminished gender pay gap among managers in turn.

Based on a data set of all the German Prime standard listed companies, we constructed a matched sample based on company and individual characteristics leading to a final matched sample of 112 female and male executive year observations. Our results show that there is a gender pay gap between female and male executives even after controlling for human capital attributes. Furthermore, with increasing embeddedness of the board of directors, the gap between female and male compensation levels decreases. This suggests that the positive aspects of board networks, i.e., the resource function, outweigh the negative facets, i.e., homophily among economic elites.

The results of our analyses contribute to research in three ways: First, in the research on unequal pay for female and male executives, this is the first time that the perspective of the deciders is examined more thoroughly. We show that deciders' impact should not be neglected and the gender pay gap is not only a result of managers' ability and character but also of the deciders' role and experience. Second, we extend the transaction costs-based language theory of discrimination by aspects of network embeddedness. Our results allow the presumption that directors gain knowledge via their embeddedness which changes their assessment of transaction costs that originate from communication and cooperation between a majority and a minority. Therefore, network embeddedness can influence the level of discrimination in the corporate world. Third, we provide further insights into the resource functions of the board of directors (Hillman et al. 2000, 2009). We offer empirical indication that the network directors are embedded which might serve as learning platform also when assessing language barriers between the majority and minorities.

\section{Literature overview, theoretical background and hypotheses}

Our study brings together two streams of research: board embeddedness research and research about determinants of executive pay, specifically the gender pay gap between female and male executives. The role of director embeddedness in corporate governance decisions already found broad attention in academia, as the following examples indicate. Researchers could for instance find evidence for the relevance of director embeddedness as an information channel in merger decisions (Haunschild and Beckman 1998). Additionally, it was shown that director embeddedness increases the embeddedness of firms and, thus increases the likelihood that firms go into joint ventures (Gulati and Westphal 1999). However, researchers could also find that director embeddedness leads to the formation of an economic elite (Allen 1974) that might not act in the interest of the firm anymore but rather optimizes its own interests. Through their embeddedness, directors learn 
to overcome their inhibitions for criminal behavior such as the backdating of options in executive compensation schemes (Bizjak et al. 2009). Generally, the effect of director embeddedness on firm level outcomes is still unclear. We thus want to shed more light into the question of the efficacy of embeddedness by the investigation of its role in situations of gender pay gap.

Research about determinants of executive pay is similarly multifaceted. Researcher showed that the level of executive compensation mainly depends on company properties as well as on personal characteristics of the manager. Firm size (Fahlenbrach 2009; Renner et al. 2002) firm performance (Antle and Smith 1986; Bebchuk and Fried 2006; Devers et al. 2007), and a firm's ownership structure (Thomsen and Pedersen 2000; Chowdhury and Wang 2009) are company properties that researchers identified as drivers of executive compensation levels. Managers' tenure (Hill and Phan 1991) and gender (Kulich et al. 2011; Renner et al. 2002), on the other hand, are personal characteristics that influence managers' compensation levels directly or as moderating effects, e.g., through affecting labor market mobility and search firms' preferences (Dreher et al. 2011). Additionally, psychological factors such as the tendency to social comparison between directors and managers influence the level of pay (O'Reilly et al. 1988). Westphal and Zajac (1995) also factor board members into decisions on compensation levels. They propose that social similarity between the board of directors and the CEO leads to higher CEO compensation. Fiss (2006) showed a similar effect for the similarity between CEO and chairman of the board. We thus acknowledge the relevance of board members in compensation decisions since the board of directors that appoints managers is also responsible for their compensation contracts and focuses on their impact on the gender pay gap ( $\$ 87$ of the German Aktiengesetz determines that the board of directors is responsible for the executives' compensation level and structure).

With respect to the issue of unequal pay for women and men, the following studies exist. Researchers identified characteristics on company as well as individual levels that drive those compensation differences (Arulampalam et al. 2007; Solberg and Laughlin 1995; Blau and Kahn 1999; Rubery 1995). The gender pay gap is very often attributed to human capital differences between women and men: Work experience due to parental leave (Blau and Kahn 2007), education received (Blau and Kahn 2001), differences in occupations (Daymont and Andrisani 1984), differences about choices concerning career, job, and family (Tharenou 2008) as well as negotiation skills (Greig 2008; Kaman and Hartel 1994), non-cognitive skills such as assertiveness and confidence (Grove et al. 2011), lower preferences for performing in a competition and lower overconfidence (Niederle and Vesterlund 2007), and expectations of what can be earned (Major and Konar 1984) are factors identified to drive the gender pay gap. Consequently, managers with a higher skill level (including better negotiation skills) should receive a higher compensation. Therefore, researchers attributed the difference in compensation to the managers' characteristics - especially their human capital. Latest studies found indications that this gender pay gap also exists beyond these human capital explanations (Kulich et al. 2011).

Thus, in summary, we identified two gaps in research that our study intends to close: First, we want to close the gap of the missing focus on executive pay, 
specifically the gender pay gap, in director embeddedness research. Second, we follow the trend of considering boards' influence in compensation decisions and close the gap of the missing focus on boards influence, specifically board embeddedness in gender pay gap literature.

\subsection{Theory of discrimination and gender pay gap}

We draw the theory of discrimination to create theoretical basis to explain a gender pay gap beyond human capital explanations and to create a basis for our investigations of the effect of embeddedness on the gender pay gap. The concept of discriminatory behavior by (Becker 1957) bases discrimination on role prejudice and explains discrimination via differences in expected task ability. The original work of Becker applies to racial minorities. Blau and Kahn (2007) use Becker's theory to explain part of the gender pay gap. However, Becker's theory became controversial as the uniqueness of good management roles became questionable since different configurations of management characteristics make successful managers. An alternative theoretical approach to comprehend the source of discriminatory behavior goes back to Lang (1986). He sees gender-specific differences in 'methods of speaking and listening' (1986: 364) as reason for discriminatory behavior. On a management team, communication is a requisite for successful cooperation. Female executives as a minority have to primarily communicate with male colleagues. From the board's standpoint, there is the threat of worsened group efficiency of the executives caused by different methods of communication. Optimal collaboration in the top management team requires that colleagues use a similar language. Otherwise, collaboration of the majority with minorities results in the emergence of transaction costs driven by different methods of communication. To prevent these group efficiency problems, generally, two options for directors exist. They could either stop appointing minorities to management positions or pass on the transaction costs to the minority by adjusting their compensation downward. In times of quota as well as social and media pressure against direct discrimination on a corporate level (Hoel 2008; Bøhren and Strøm 2010), the most obvious option for board members to price in the expected transaction costs of appointing a minority is to reduce the allowed compensation paid to that minority.

\subsection{Network embeddedness effects on discrimination}

The level to which board members will assess these transaction costs depends on their evaluation of the size of the language barrier. Board members' network embeddedness can have different effects on this assessment. Network embeddedness refers to the extent to which board members are connected to their peers via multiple directorships, thereby connecting the focal company to others (Geletkanycz and Boyd 2011; Boyd 1990). It affects board members' cognition of the corporate context and corporate relations (Shropshire 2010). The direction of the expected embeddedness effect on the hypothesized gender pay gap is ambiguous, however. We identify two competing theories that will result in two opposing 
hypotheses: homophily among members of the economic elite versus resource provision and learning function of embedded boards.

Networks lead to the formation of elites (Davis and Greve 1997; Useem 1982). With respect to gender, these elites are predominately male (Daily et al. 1999; Bilimoria and Piderit 1994, Brammer et al. 2009; Adams and Ferreira 2009; Huse et al. 2009; Hillman et al. 2007). Among groups with similar demographical attributes, homophilous behavior can be observed (McPherson and Smith-Lovin 1987). The argument of homophilous behavior is derived from the concept of social similarity (McPherson et al. 2001; Wellman 1926)—meaning that individuals are acting in favor of other individuals that are similar to themselves (Pearce and $\mathrm{Xu}$ 2012). The underlying argument is the individuals' expectation of the similarity of values, interests and norms of individuals with similar demographical characteristics (Ibarra 1992; McPherson et al. 2001). As early as 1950, homophily was observable among American CEOs, who were mainly white, Protestant and born to nonimmigrant, urban families (Mills 1956). The individual visualizes that similar demographic attributes mean sharing similar agendas (Dutton et al. 2002). On board level, Westphal and Stern (2007) showed that, compared to the majority, dissimilar directors were not rewarded as much for expected behavior as well as punished more for socially not appreciated behavior.

Applying the argumentation of homophily and social similarity on Lang's (1986) transaction costs interpretation of discrimination, the affiliation with a network affects the assessment of the transaction costs. To work effectively, managers have to communicate with their colleagues. The existence of communication barriers might cause the emergence of transaction costs. Communication barriers are higher between a majority and a minority than within a socially similar group. When appointing a new manager, the board of directors has to evaluate the fit of the candidates to the existing management team and assess the resulting transaction costs. The board members' psychological cognition influences this assessment. Board members who behave more homophilously due to their elite network affiliation assess communication barriers between a minority and the majority and the resulting transaction costs higher. This assessment leads to a decision in favor of the majority as well as a higher discount in compensation levels for minority managers, respectively. The assessment of communication barriers and transaction costs between minorities and the majority, therefore, increases with the directors' embeddedness into an elite network, and consequently leads to an increase of the gender pay gap.

H1: Director embeddedness increases the gender pay gap.

An alternative way to see the network is in a positive light of a learning platform and information channel (Hillman and Dalziel 2003; Carpenter and Westphal 2001; Lynall et al. 2003; Harris and Shimizu 2004; Shropshire 2010). A higher assessment of language barriers with minority managers could be a product of stereotypes and lack of experience. In the absence of precise information, stereotypes are more probable to affect individuals' cognition (Bielby and Baron 1986) and substitute de facto knowledge channels (Plaks and Tory Higgins 2000). By serving on different boards, a director experiences different company cultures and different individuals 
who may not belong to the majority group the director feels associated with. Via their networks, board members can gain experience about communication skills of other board members and managers, especially those the directors are unfamiliar with due to social dissimilarity. A multitude of board seats, furthermore, gives the directors the opportunity to experience the benefits of diversity first hand. Network embeddedness and its utilization as a learning platform then lead to a reduction of preconceptions and discrimination of female managers. Thus, the actual knowledge gained through network embeddedness reduces the reliance on stereotypes, reduces the assessment of communication barriers and transaction costs between the majority and a minority, and in turn decreases the gender pay gap among managers.

H2: Director embeddedness reduces the gender pay gap.

\section{Sample and data}

In the following part, we describe the properties of our sample and the method of deriving it.

\subsection{Sample definition}

The German law VorstOG of 2005 (law passed in 2005 that made it mandatory for companies to disclose the individual compensation of their managers unless the annual shareholders' assembly vetoes this' has made it mandatory for German-listed companies to disclose the compensation of their managers. We base our research on the companies listed in the German Prime Standard (market segment with the highest disclosure and reporting standards for German listed companies) during the years 2005 until 2009 and rely on a matched sample for our analyses (Arthaud-Day et al. 2006; Cannella et al. 1995; Kulich et al. 2011). We exclude financial companies from the sample-identified by an SIC code between 6,000 and 6,799 (Farrell et al. 2008) - because their firm characteristics such as leverage and total assets (important control variables for our matching and regressions) differ from those of non-financial companies and would thus lead to estimation biases. The final database consists of an unbalanced panel of 1,458 firm years. This sample covers 4,731 executive year positions.

We constructed our matched sample in two steps due to the relatively small number of female executives in German companies and to incorporate both company properties and personal characteristics that might affect the level of compensation (e.g., Renner et al. 2002; Kulich et al. 2011). We first identified female executives on the basis of annual reports, the Hoppenstedt Aktienführer (German periodical similar to Moody's manuals), Lexis-Nexis and inquiries to investor relation departments. For every identified woman, we hand collected the following data for the respective year she served as an executive: her functional responsibilities, her age and tenure as well as the compensation received. Next, we used Propensity Score Matching (Rosenbaum and Rubin 1983) at the company level to match five nearest neighbor companies without a female executive to every 
company with a female executive for the respective year (Leuven and Sianesi 2003; Santaló and Kock 2009). The purpose of this procedure is to find comparable male managers for the female managers of our sample. Thus, in a first step, we try to find comparable companies to the companies with female managers. For this reason, we use the STATA command psmatch2 (Leuven and Sianesi 2003) which provides us the five most comparable companies to the company with the female manager based on predefined input variables (in our case company size and performance). The variables for this matching were company size and performance-two properties identified as main drivers of compensation in earlier studies (Rapp and Wolff 2010; Fahlenbrach 2009). Bertrand and Hallock (2001) identified company size as a reason for unequal compensation between female and male managers since on average female top managers appeared to work for smaller companies than male peers which in turn negatively impacts their compensation levels. Renner et al. (2002) see company size as a proxy for responsibility an executive has. The increased responsibilities in larger companies, therefore, require higher compensations.

Table 1 Descriptive statistics of the used variables

\begin{tabular}{|c|c|c|c|c|c|c|}
\hline & \multicolumn{5}{|c|}{ Panel A: descriptive statistics } & \multirow{2}{*}{$\begin{array}{l}\text { Panel } \\
\text { B: } \\
\text { VIF } \\
\text { Max. } \\
\text { VIF }\end{array}$} \\
\hline & Mean & SD & Min & Max & Obs & \\
\hline COMPENSATION & 6.168 & 0.952 & 2.565 & 7.929 & 122 & - \\
\hline WOMAN & 0.500 & 0.502 & 0.000 & 1.000 & 122 & 5.39 \\
\hline TENURE & 3.139 & 1.482 & 0.000 & 5.258 & 122 & 2.19 \\
\hline AGE & 6.333 & 0.134 & 6.010 & 6.750 & 122 & 2.30 \\
\hline COMPANY_AGE & 2.048 & 1.038 & 0.000 & 4.090 & 122 & 4.91 \\
\hline EMPLOYEES & 7.452 & 2.317 & 3.401 & 12.912 & 122 & 5.31 \\
\hline LEVERAGE & 0.201 & 0.183 & 0.000 & 0.732 & 120 & 2.28 \\
\hline ROE & 5.168 & 23.169 & -74.470 & 38.056 & 122 & 2.14 \\
\hline TOBIN'S Q & 1.716 & 0.849 & 0.622 & 5.178 & 120 & 2.06 \\
\hline RISK & 0.218 & 1.709 & -4.990 & 7.750 & 120 & 1.74 \\
\hline \#EXECUTIVES & 3.869 & 1.590 & 1.000 & 8.000 & 122 & 4.22 \\
\hline \#COMMITIEES & 1.951 & 1.781 & 0.000 & 7.000 & 122 & 4.60 \\
\hline PERCENTAGE_EXECUTIVES & 0.178 & 0.196 & 0.000 & 0.750 & 120 & 2.37 \\
\hline BOARD_TENURE & 4.237 & 2.626 & 0.000 & 11.750 & 122 & 3.39 \\
\hline EXTERNAL_BLOCKHOLDER & 0.492 & 0.502 & 0.000 & 1.000 & 122 & 2.77 \\
\hline OWNER_CONTROLLED_MANAGING_BOARD & 0.254 & 0.437 & 0.000 & 1.000 & 122 & 3.05 \\
\hline FEMALE_DIRECTOR & 0.492 & 0.502 & 0.000 & 1.000 & 122 & 3.40 \\
\hline AVG_NUMBER_OF_INTERLOCKS & 1.621 & 1.135 & 0.000 & 4.500 & 118 & 4.43 \\
\hline EIGENVECTOR_CENTRALITY & 0.008 & 0.023 & 0.000 & 0.148 & 118 & 2.31 \\
\hline
\end{tabular}

Table 1 shows the descriptive statistics for the variables in the matched sample 


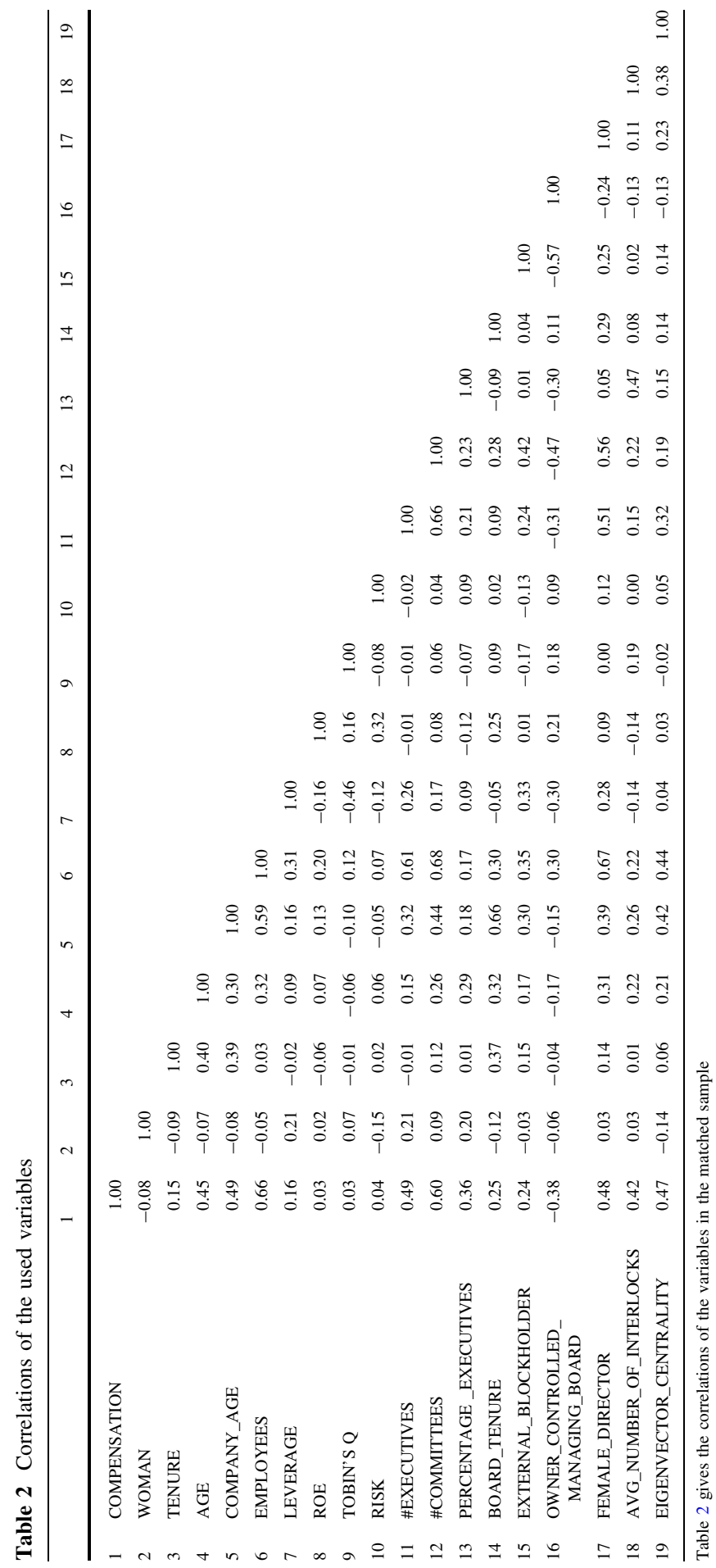


After this automated matching at the company level, we matched the most similar male executive of the five nearest neighbor companies to every female executive based on their respective functional responsibilities. An automated matching was not possible in this step due to the different nomenclature for the respective functional responsibilities across companies as well as the possibility of a manager's responsibility for multiple functions at the same time. Furthermore, some companies are structured by division and others by function. In this step, we allow that a female manager who is in our sample for more than 1 year can have different male matches over the year. In this way, we can avoid matching biases in our results due to changes in functional responsibilities of the female or the male manager from 1 year to the other. We then collected the same data for the male control group as for the female executives in the first step.

The strength of the resulting sample is the 1:1-matching of personal and firm years. Conditions for being included in the regressions are the following: First, for some individuals, data on compensation received were not available. This possibility exists because of an opt-out rule specified in the VorstOG which enables shareholders to veto the individual disclosure of the company's executives' compensation ( $\$ 286$ subparagraph 5). Second, the compensation packages had to be comparable and, therefore, we only included executives with 12 months of tenure per year. These adjustments yield a matched sample of overall 122 executive/firm years (61 male and 61 female). 112 of them were included in the calculated models due to the partial unavailability of control variables. To provide evidence for the equivalency of the two sub-samples, we tested for the sub-samples' equality with regard to firm size, firm performance as well as ownership structure (Arthaud-Day et al. 2006). The results indicated no differences of statistical significance between the female and the male sub-samples.

Sources for personal characteristics were mainly companies' annual reports as well as the Hoppenstedt Aktienführer. Company properties originated from two sources: The Thomson Financial Worldscope database delivered information such as number of employees and financial data (e.g., return on equity). Corporate governance variables concerning the board and ownership structure of a company originate from business reports as well as the Hoppenstedt Aktienführer. Some of the used data were also part of a project with the German Federal Ministry of Family Affairs, Senior Citizens, Women and Youth (Lindstädt et al. 2011). Table 1 gives an overview of the variables' descriptive statistics and Table 2 shows their pairwise correlations.

\subsection{Variables}

The dependent variable of our analysis is COMPENSATION which equals the amount of compensation received by the focal executive in the respective year denoted in thousand Euros. This amount is composed of the fixed salary, the performance-based compensation (bonus and stock-based incentives) and fringe benefits usually paid for company cars and telecommunication devices. We did not include pension benefits and single payments due to the lack of a clear rule of disclosure for these parts as well as the non-comparability across companies. We 
used the natural logarithm of the total amount to reduce heteroskedasticity (Boyd 1994; Brenner and Schwalbach 2003; Finkelstein and Hambrick 1989) and to control for skewness (Casciaro and Piskorski 2005; Fahlenbrach 2009). We made the results robust against outliers by winsorizing the variable on the $1 \%$ level (Kuhnen and Niessen 2012).

The dummy variable WOMAN is the explaining variable that enables us to analyze the gender pay gap. It is a dummy variable that equals 1 if the executive is female and 0 otherwise.

The sets of control variables depict personal characteristics and company properties. At the personal level, we include the variables AGE to account for the age of the executive as well as TENURE to control for senior leadership experience (Vieito and Khan 2012; Hill and Phan 1991). Both are measured in the natural logarithm of the respective time spans measured in months (Masulis and Mobbs 2012; Alissa 2009; Vieito and Khan 2012).

At the company level, we control for financial, company and corporate governance characteristics. As financial characteristics, we use LEVERAGE (quotient of total debt to total assets) as a proxy for the company's capital structure (Shaw and Zhang 2010) as well as the variable RISK (standard deviation of the operating performance over the focal and the 2 preceding years divided by their mean-winsorized to guard from outliers) to depict firm risk. We incorporate an accounting-based as well as a stock-based measure for firm performance (Kulich et al. 2011; Adams and Ferreira 2009), i.e., the company's ROE and TOBIN'S Q, respectively, to control for their effects on executive compensation (Antle and Smith 1986; Bebchuk and Fried 2006; Devers et al. 2007).

Company characteristics include the variable EMPLOYEES as a proxy for company size (Renner et al. 2002; Fahlenbrach 2009) measured as the natural logarithm of the total number of employees (Zona et al. 2013); and COMPANY_AGE (Musteen et al. 2010) measured as the natural logarithm of the number of years since the company's IPO.

The corporate governance characteristics include the variable \#EXECUTIVES which represents the number of executives including the focal manager. The ownership structure (Thomsen and Pedersen 2000; Chowdhury and Wang 2009) is represented by the two dummy variables EXTERNAL_BLOCKHOLDER and OWNER_CONTROLLED_MANAGING_BOARD. We also control for the following board characteristics expecting a lower compensation with more efficient boards: \#COMMITTEES measures the number of committees composed by the board and might decrease control efficiency of the board since decisions can be made in small groups and do not necessarily have to be defended in front of all board members. BOARD_TENURE is the mean value of all directors' tenures on the focal board and might affect executive compensation since on the one hand tenure reduces board independence but on the other hand it increases firm level experience of directors which enables them to a stricter argumentation in bargaining situations. PERCENTAGE_EXECUTIVES refers to the percentage of directors who are currently executives in another company which, e.g., provides them better access to benchmark information about acceptable compensation levels. Specific to our research question, we also control for the gender composition of the board 


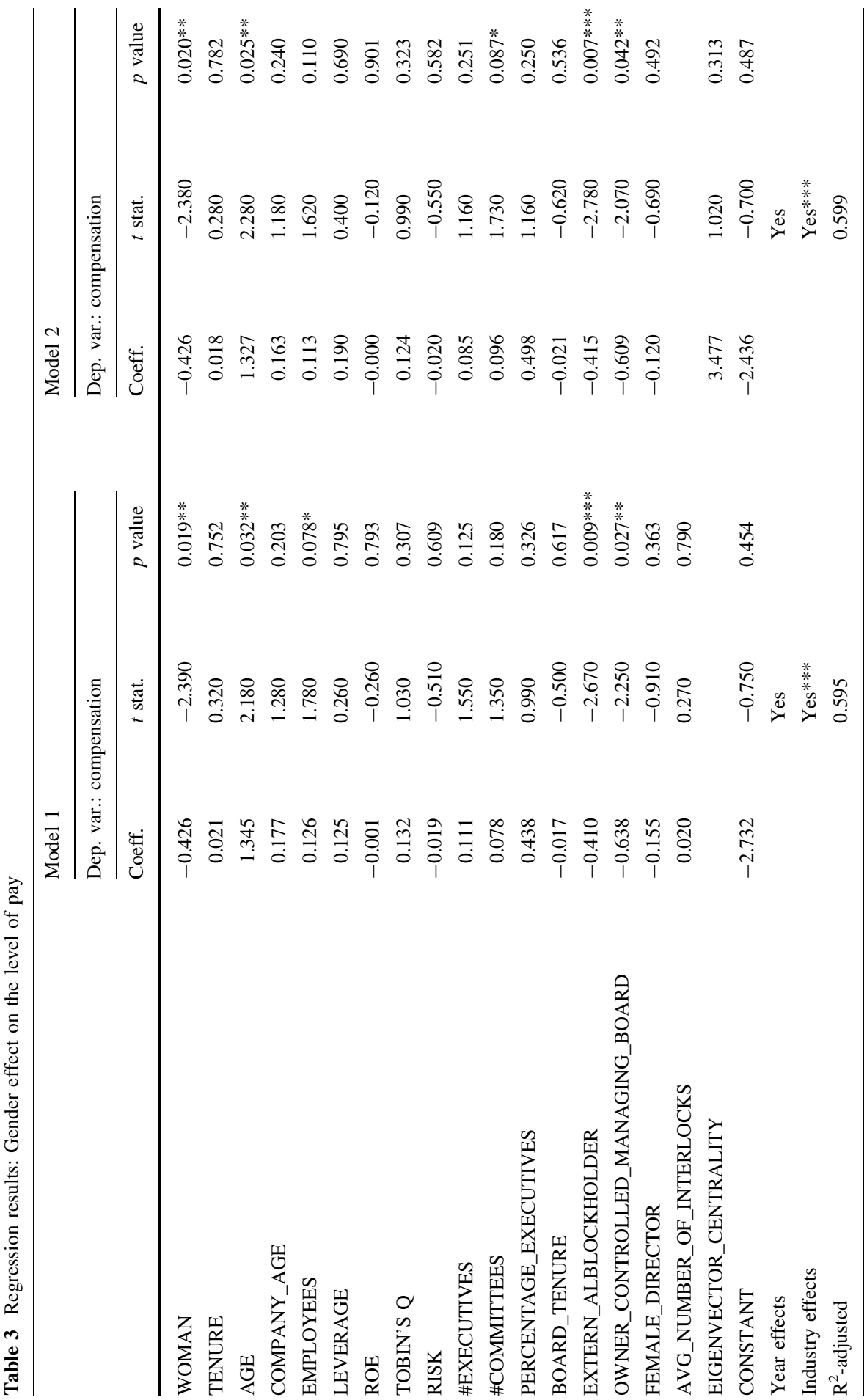




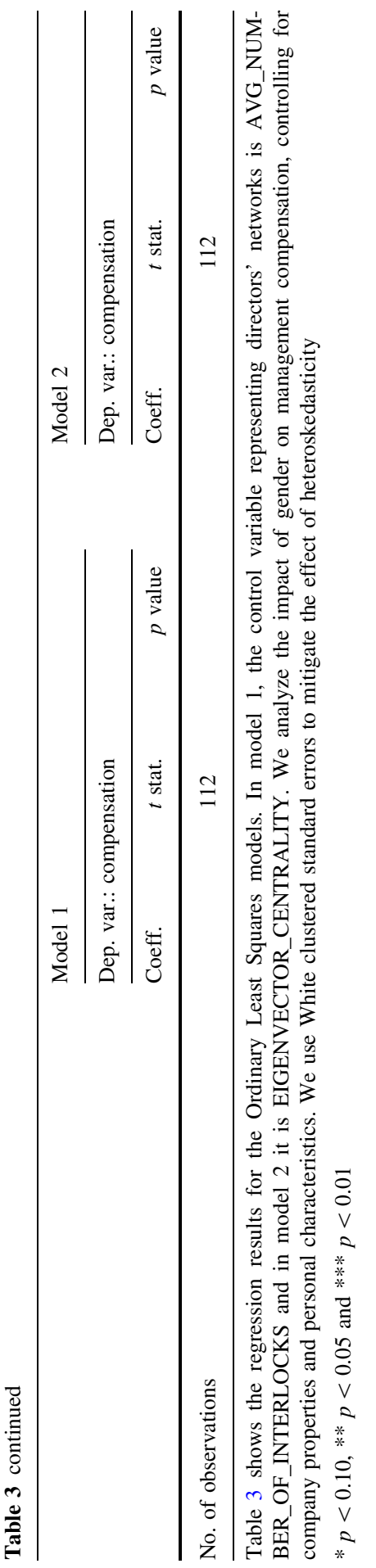


(Duchon et al. 1986) by including FEMALE_DIRECTOR, a dummy variable equaling 1 if at least one female director is a member of the board.

We use two proxies to capture the aggregate embeddedness of the boards: Researchers have shown that interlocks have an impact on learning and the spread of practices through a network (Davis 1991). AVG_NUMBER_OF_INTERLOCKS measures the average number of additional board seats the directors of the focal board hold. It depicts the opportunity of the directors to gain knowledge and experience first-hand. Additionally, we incorporate a measure of centrality into our model (Renneboog and Zhao 2011; Ahuja et al. 2009; Shipilov et al. 2010). EIGENVECTOR_CENTRALITY is the average eigenvector centrality of all members of the focal board. The idea behind this variable is to distinguish between more and less important interlocks. The relative importance is determined by the centrality of the directors the focal director is connected with (Bonacich 1972, 1987). Values are calculated by solving the following linear equation: $C_{E}(i, t)=\frac{1}{\lambda} \sum_{j, i \neq j} a_{i j} * C_{E}(j, t)$, with $C_{\mathrm{E}}$ equaling the eigenvector centrality, $a_{i j}$ equaling the entries of the adjacency matrix A and meaning that $i$ contributes to $j$ 's status and $\lambda$ equaling the largest eigenvalue (Bonacich and Lloyd 2001). This means that director $i$ is more central, the more central his contacts $j$ are. The equation is solved by an iterative algorithm. It is a measure that captures how much the directors are part of the nationwide elite network. Centrality within a network is often related not only to a fast spread of knowledge and experience (Shipilov and Li 2008; Shipilov et al. 2010) but also to homophilous behavior. By incorporating both of these measures, we are able to capture both the resource and learning function and the economic elite concept of the network embeddedness.

Table 5 in the Appendix gives an overview of the variables and their respective definitions.

\section{Empirical results}

At first, we explain the empirical design before we show the results and their robustness.

\subsection{Empirical design}

As stated in the first hypothesis, we expect a gender pay gap even after controlling for various other effects on the personal and company levels. Therefore, we specify our main model as:

COMPENSATION $=f($ Gender, Personal Characteristics, Company Properties $)$.

In accordance with the further research design of the second step, we test this main model into two versions, one with AVG_NUMBER_OF_INTERLOCKS and one with EIGENVECTOR_CENTRALITY as control variable depicting the directors' network embeddedness. To test hypotheses 1 and 2, we then include 
the interaction terms WOMAN * AVG_NUMBER_OF_INTERLOCKS and WOMAN * EIGENVECTOR_CENTRALITY, respectively, in the regression to determine whether a more embedded board increases or decreases the gender pay gap.

In all cases, we use a pooled Ordinary Least Squares (OLS) regression to test the hypotheses. The OLS method is the obvious choice of method because our pairs of female and male executives do not stay the same across years which makes panel data methods unemployable. We include year and industry effects defined by the Fama/French-12 industry logic (Fama and French 1997). To guard our regression against heteroscedasticity, we use Huber/White standard errors (White 1980; Petersen 2009). Further, we report the maximum variance inflation factor (VIFs) for each variable (see Table 1): Values equal or beneath 5.39 indicate that the problem of multi-collinearity can be rejected (Shipilov et al. 2010; Harris and Shimizu 2004).

\subsection{Regressions results}

\subsubsection{Gender pay gap}

The models in Table 3 show strong support for the existence of a gender pay gap although the managers are comparable with respect to their human capital. The variable WOMAN is significant at the $5 \%$ level $(t=-2.39 /-2.38)$ and the coefficient is negative $(\beta=-0.426 /-0.426)$. This result indicates that even after controlling for human capital variables as well as various other influences, a female executive still receives a lower compensation than a comparable male. Thus, human capital which researchers identified as main reason for the gender pay gap (Bowles et al. 2007; Blau and Kahn 2007; Solberg and Laughlin 1995; Kaman and Hartel 1994) is not the only driver of compensation levels. With this result, we show that a pay gap among German executives in fact exists. This result falls in line with studies for other geographical regions (e.g., Renner et al. 2002).

\subsubsection{Gender pay gap and directors' embeddedness}

Table 4 shows the results for the OLS regression with the additional incorporation of the interaction effects WOMAN * AVG_NUMBER_OF_INTERLOCKS and WOMAN * EIGENVECTOR_CENTRALITY, respectively. According to these results, hypothesis $\mathrm{H} 1$ can be rejected and $\mathrm{H} 2$ can be supported. The model shows a significant positive effect on the $5 \%$ level of the interaction term $(\beta=0.217$, $t=2.08$ and $\beta=16.192, t=2.31$ ). Figure 1 illustrates the interaction effects based on state of the art plotting procedures (Aiken and West 1991; Tang et al. 2011). These results support the hypothesis that director embeddedness reduces gender discrimination through unequal executive compensation and can be used as further indication that embedded directors might use the multitude of board seats as a learning platform (Shropshire 2010; Hillman et al. 2007; Haunschild and Beckman 1998). The experience that directors gain via their network embeddedness might affect their assessment of language barriers and proposed transaction costs in a 


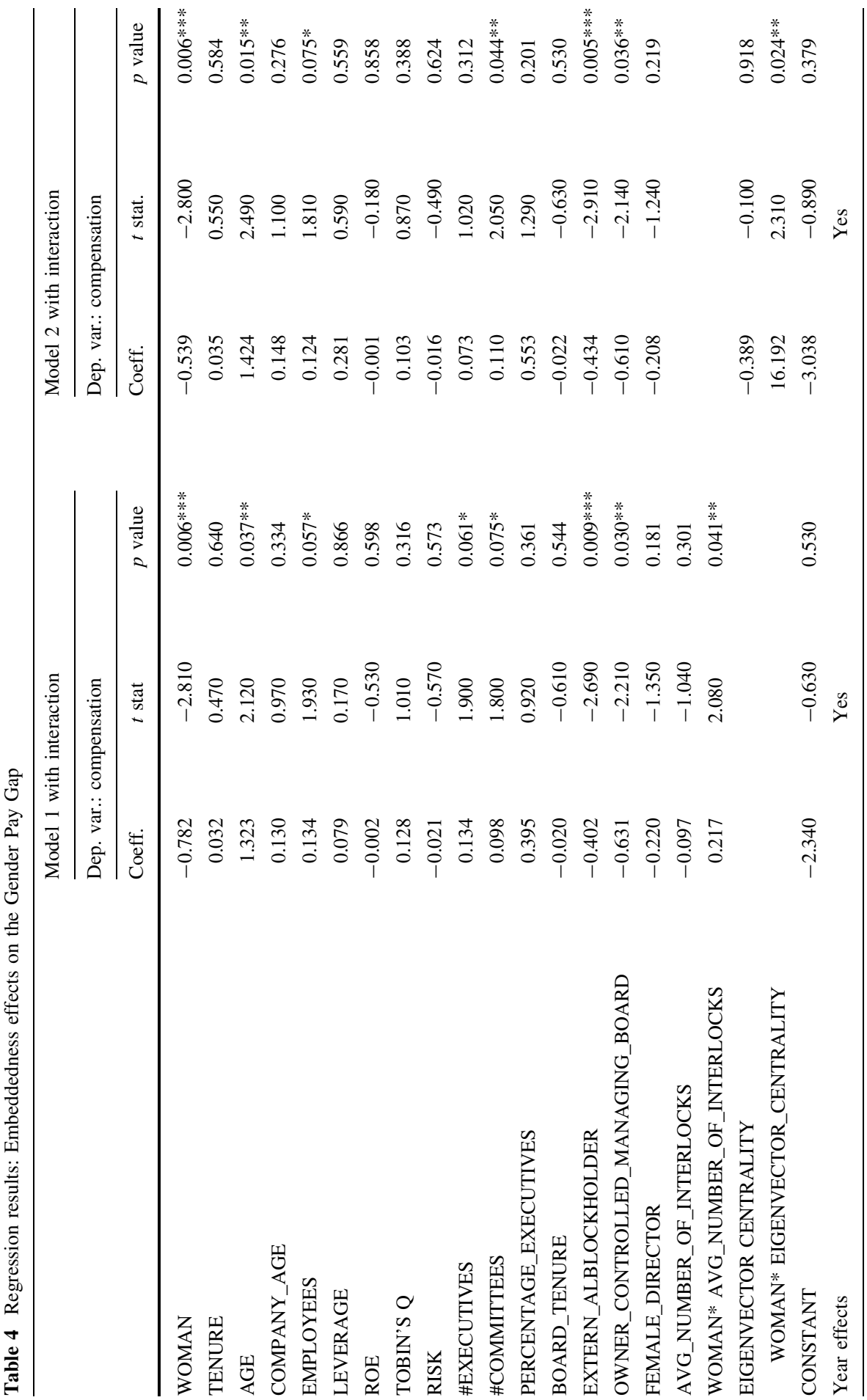




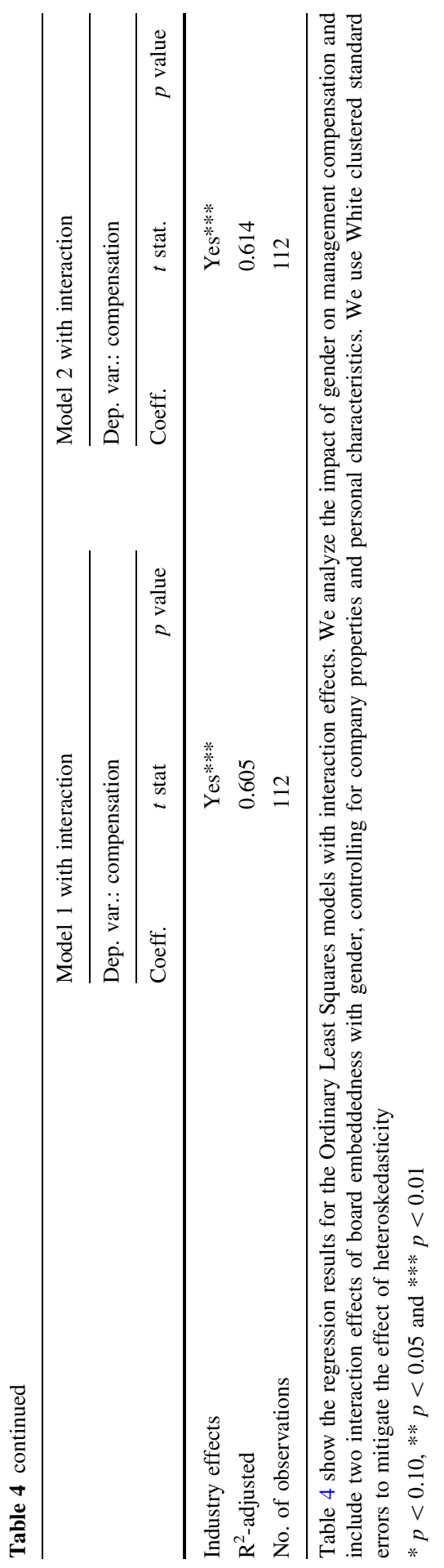



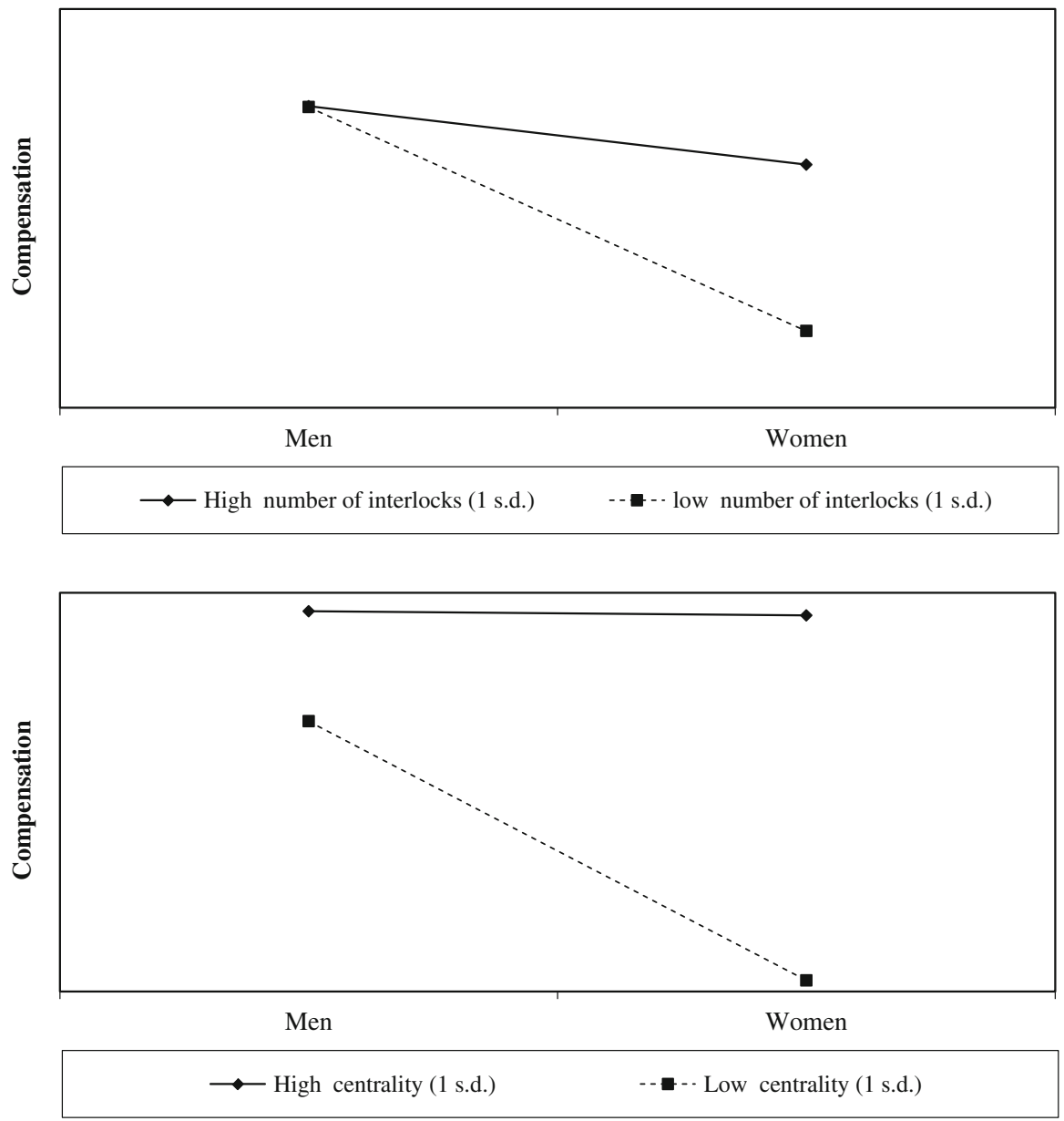

Fig. 1 Moderating effects of number of interlocks and centrality on the relationship between gender and compensation

positive way and reduce the compensation discount that is passed on to female managers. The positive influence of the learning platform, therefore, outweighs the sentiment of homophily and elite status.

\subsection{Robustness tests}

To show the robustness of our results, we challenged them on two different levels. First, we re-calculated our model with different proxies for some of the independent variables yielding the same results qualitatively: instead of EMPLOYEES as a proxy for company size, we used ASSETS as well as SALES, i.e., the natural logarithm of the company's total assets/net sales in the focal year (Baranchuk et al. 
2011; Elston and Goldberg 2003; Shipilov et al. 2010). We also used another definition of leverage using long-term total debt divided by total assets. Instead of the dummies EXTERNAL_BLOCKHOLDER and OWNER_CONTROLLED_MANAGING_BOARD to depict the ownership structure, we used the percentages of shares held by different groups of investors: MANAGEMENT_OWNERSHIP for members of the management team, PRIVATE_OWNERSHIP for private owners who are not part of the management team BANK_OWNERSHIP for banks, and INDUSTRY_OWNERSHIP for other companies. Additionally, we changed the control FEMAL_DIRECTOR from a dummy to a percentage variable and our results remained stable. We also changed the accounting-based and stock-based company performance measures and received the same results. Instead of the return on equity, we used the OPERATIVE_PERFORMANCE (calculated as operative income after depreciation divided by the mean of total assets of the focal and the previous year) as well as the return on assets ROA, and instead of TOBINS' $Q$ we also used DIVIDEND YIELD (dividends per share divided by market price at year end). Furthermore, we challenged our results by substituting both performance measures with the respective values of the previous year as well as with the average of the focal and the previous year.

Second, we gave further robustness to our results by altering the dependent variable. To preempt the suspicion that the pay gap might be driven by differences in the performance-related compensation of females and males, we used the natural logarithm of the executives' fixed salary as dependent variable and received the same results as with total compensation. This check exhibits that the results regarding the indirect discrimination as well as the influence of directors' embeddedness are not only driven by different performance-based compensation components between female and male executives.

\section{Discussion and conclusion}

We started our research with the question whether a gender pay gap exists in management compensation and whether this relation between managers' gender and their compensation was moderated by director embeddedness. Drawing on an economics-based perception of discrimination, we model directors' role in the decision process on compensation contracts for female and male managers via transaction costs. This transaction cost model of discrimination allows us to integrate psychological aspects, i.e., homophily, and resource dependence theorybased ideas of networks as learning platforms into the classical agency decision on the level of manager compensation.

Our results are in detail that first, a pay gap between female and male managers is observable even after controlling for aspects of human capital. Second, the network that board members create with further board seats on other companies' boards reduces this pay gap. This is in line with existing studies which argue that the network works as a learning platform (Hillman and Dalziel 2003; Shropshire 2010; Carpenter and Westphal 2001; Haunschild and Beckman 1998; Geletkanycz and 
Boyd 2011). The results indicate that the experience of other board positions might provide directors with the information they need to overcome their presumption of language barriers. In turn the occurring transaction costs are assessed lower, the discount on female manager's compensation levels is smaller and the gender pay gap decreases.

Our research contributes to the existing literature on top management compensation by taking the deciders' perspective. For the first time, the deciders' preferences were chosen to explain the gender pay gap. We show that this dimension plays a viable role in compensation setting and, therefore, the formation of unequal pay of female and male mangers. Our analyses integrate language theory which uses transaction costs as an explanation of discrimination and the theory of network embeddedness. The combination of these two theories enables us to explain further parts of the gender pay gap that have not been accounted for so far and at the same time identify a lever to reduce it. Network embeddedness can provide directors knowledge they can use to better assess transaction costs incurred by the company due to communication and cooperation between a minority and a majority group. Thus, our results offer an indication how embeddedness of directors might impact the discrimination that occurs in the corporate world. We also provide further insights into the resource functions of the board of directors (Hillman et al. 2000, 2009). We propose that director networks serve as positive learning platforms instead of negative elite networks where members only try to further their power and influence. Via their network embeddedness, directors gain more experience with minority groups which reduces their presumption of language barrier and leads to a more accurate assessment of the skills and character of a minority manager.

Additionally, we identify a gender pay gap on the level of executives in Germany. This is the first in-depth analysis of this group and the results confirm similar findings for other institutional environments, such as the US (Renner et al. 2002) and the UK (Kulich et al. 2011).

Although we are able to control for many effects, our research is not without limitations. Some information that might also impact the gender pay gap is not disclosed in a way that makes collecting it possible without a bias (e.g., number of children, time of parental leave, time worked part-time, and percentages of women in the companies' workforce). Furthermore, our sample size does not allow us several interesting additional contingency investigations, such as the specific experiences directors make in their network or specific industry affiliations of the firms, or other interesting model specifications such as the inclusion of industry affiliation as matching criterion. Due to the size of our sample, we unfortunately end up with too small subsamples in these kinds of analyses. With 112 manager year positions, our sample is rather small. However, this small number occurs due to the fact that there are not many women in executive positions in German Prime Standard companies. Although the sample size is small, we do not have to suspect selection biases since our study is based on a complete count of the Prime Standard. Extending our study beyond the Prime Standard is not possible since these General Standard companies are 
subject to different reporting requirements and, therefore, for our study required data are not available. Additionally, the sample size restricts us in addressing potential problems of endogeneity and reverse causality empirically. For instance, we cannot assure the strict exogeneity of our moderator and, thus we cannot exclude that individuals with a lower taste for discrimination are more likely to serve on multiple boards, respectively, that board members are able to gain multiple board seats due to their openness towards diversity. These limitations concerning endogeneity and reverse causality also have to be kept in mind when interpreting our results. Formally, our empirical results only indicate correlations and no causal relations. A larger sample would enable us to calculate our empirical models using generalized methods of moments (GMM) (Arellano and Bond 1991) which have been implemented in prior studies (Hillier et al. 2011; Pathan 2009) since it is amenable to reduce problems of endogeneity, i.e., a possible correlation between the explanatory variables and the error term. In summary, we hope that we could encourage researchers to extend our study concerning these sample size issues whenever Germany reached the critical mass of female managers to make these kinds of analyses possible.

We are also not able to incorporate the personalities of the managers. This would be useful for various reasons. First and often stated, women negotiate differently than men (Kulik and Olekalns 2012; Bowles et al. 2007; Greig 2008) and have different preferences for performing in a competition (Niederle and Vesterlund 2007). It would be interesting to see whether these ideas still hold in the highest echelons of companies considering that the female managers who are at that level had to get there in part by negotiation and by facing competition. Second, the appointment process consists of conversations between directors and candidates that are both formal and informal. If personalities do not match and there is a dislike between both sides, the result can be lower pay. Qualifications might only play a minor role in that part of the negotiation. Data generation is rather difficult in these areas of research as it is nearly impossible to gather unbiased questionnaire data on this hierarchical level of large organization or conduct experiments that are close to reality. However, questionnaires could generate further insights into the negotiation strategies, expectations and preferences of both sides-managers that negotiate for their compensation and directors that finally decide on the pay levels.

Furthermore, beyond a gender pay gap, we suggest to extend research analyzing possible pay gaps attributed to different minority groups. The level of a pay gap can be used as indicator for the strength of indirect discrimination. Combinations of diversity parameters are interesting to be analyzed, because the social identity has more than one dimension, e.g., gender and race (Ashkanasy et al. 2002). However, investigations of this kind require a different dataset than Germany, because the variation in race, religion or ethical background is not large enough to provide representative conclusions - a US context might be more suitable for this type of analysis. 
In spite of these limitations, our results can still have some practical implications: We show that companies can receive valuable insights from embedded directors. A company with a more embedded board has an advantage over a company without an embedded board for several reasons: As previous studies have shown, knowledge and experience are important resources for directors to fulfill the tasks they are employed to carry out (Ahern and Dittmar 2012; Haunschild and Beckman 1998). We can now extend the benefits of embeddedness with the potential reduction of discrimination. Our empirical results allow the presumption that embedded directors base their decisions about appointments and compensation contracts less on stereotypes. In turn, they offer suitable candidates more competitive compensation contracts and therewith increase the firms' chances of attaining and retaining capable and competent executives. These benefits are not restrained to management compensation, however: They are possible on all hierarchical levels. Knowledge and experience might help to reduce presumptions of language barriers and therewith stereotypes about minority groups among the majority workers of a company. One possibility for companies to establish an environment of reduced stereotypes and equal opportunities is, therefore, the creation of alternative knowledge sources such as trainings or cross-mentoring programs. Implementing such trainings to professionalize the board might be beneficial if its members are not yet embedded in networks. This is also a possible lever for regulators: Pushing for such trainings to be mandatory could improve the corporate governance of the country as a whole.

This paper offers a different perspective on explaining unequal compensation of female and male executives. We propose a closer look at the deciders' side of management compensation and the communication barriers between majority and minority groups. Discrimination by the board has an impact on the gender pay gap. Embeddedness as a proxy for learning can decrease the extent of the inequality and can increase the quality of boards.

Acknowledgments The authors would like to thank the reviewers and participants of the 72nd Annual Meeting of the Academy of Management in Boston as well as the reviewers and participants of the Annual Congress of the German Academic Association for Business Research (VHB) for their constructive and positive feedback. Furthermore, we thank our editor Thomas Hutzschenreuter as well as our two anonymous reviewers for their helpful and constructive comments. Michael Wolff would additionally like to thank the German Federal Ministry of Family Affairs, Senior Citizens, Women and Youth for their support during the data collection process.

Open Access This article is distributed under the terms of the Creative Commons Attribution License which permits any use, distribution, and reproduction in any medium, provided the original author(s) and the source are credited.

\section{Appendix}

See Table 5 for an overview of all variables and their definitions and sources. 


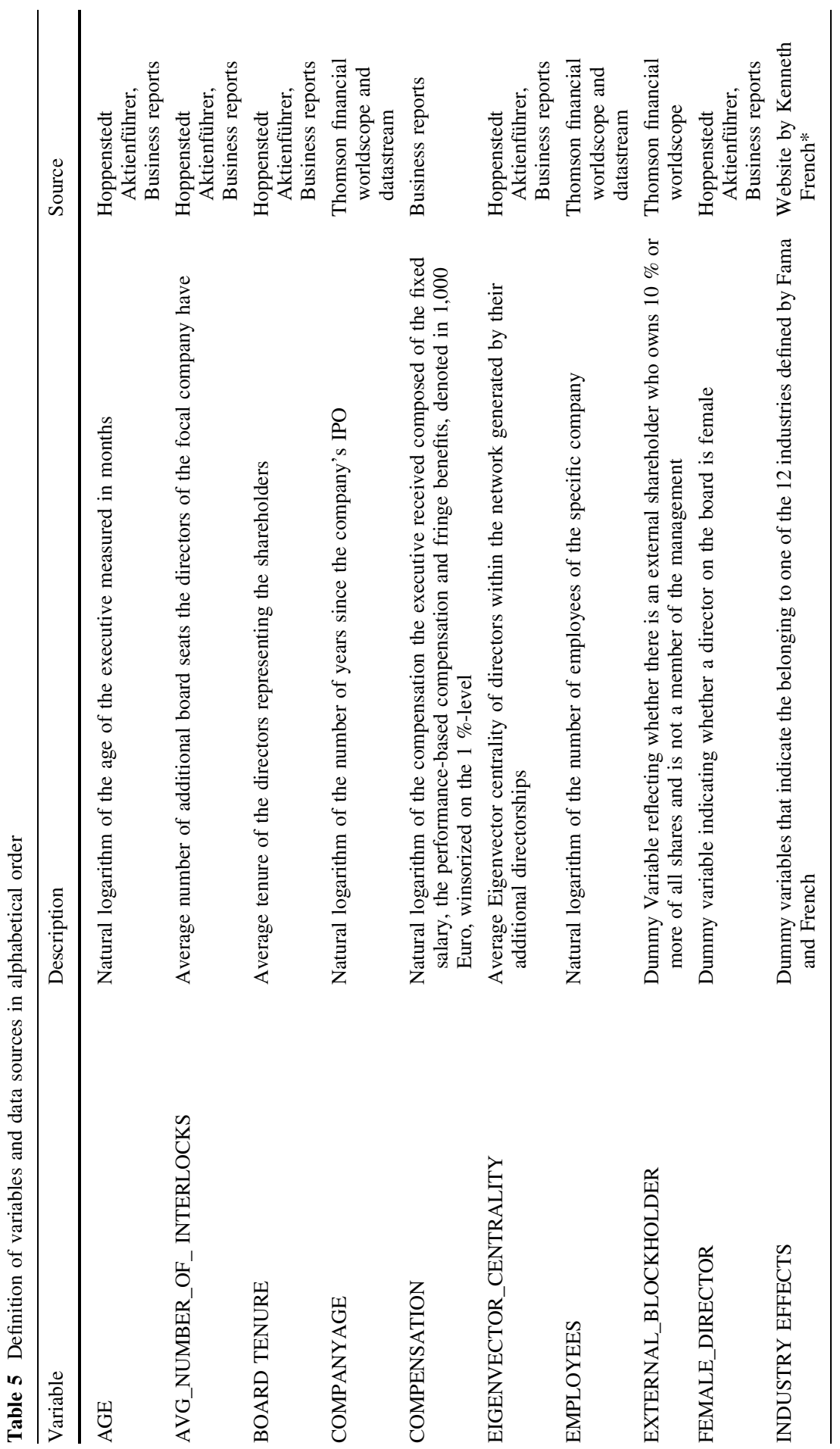




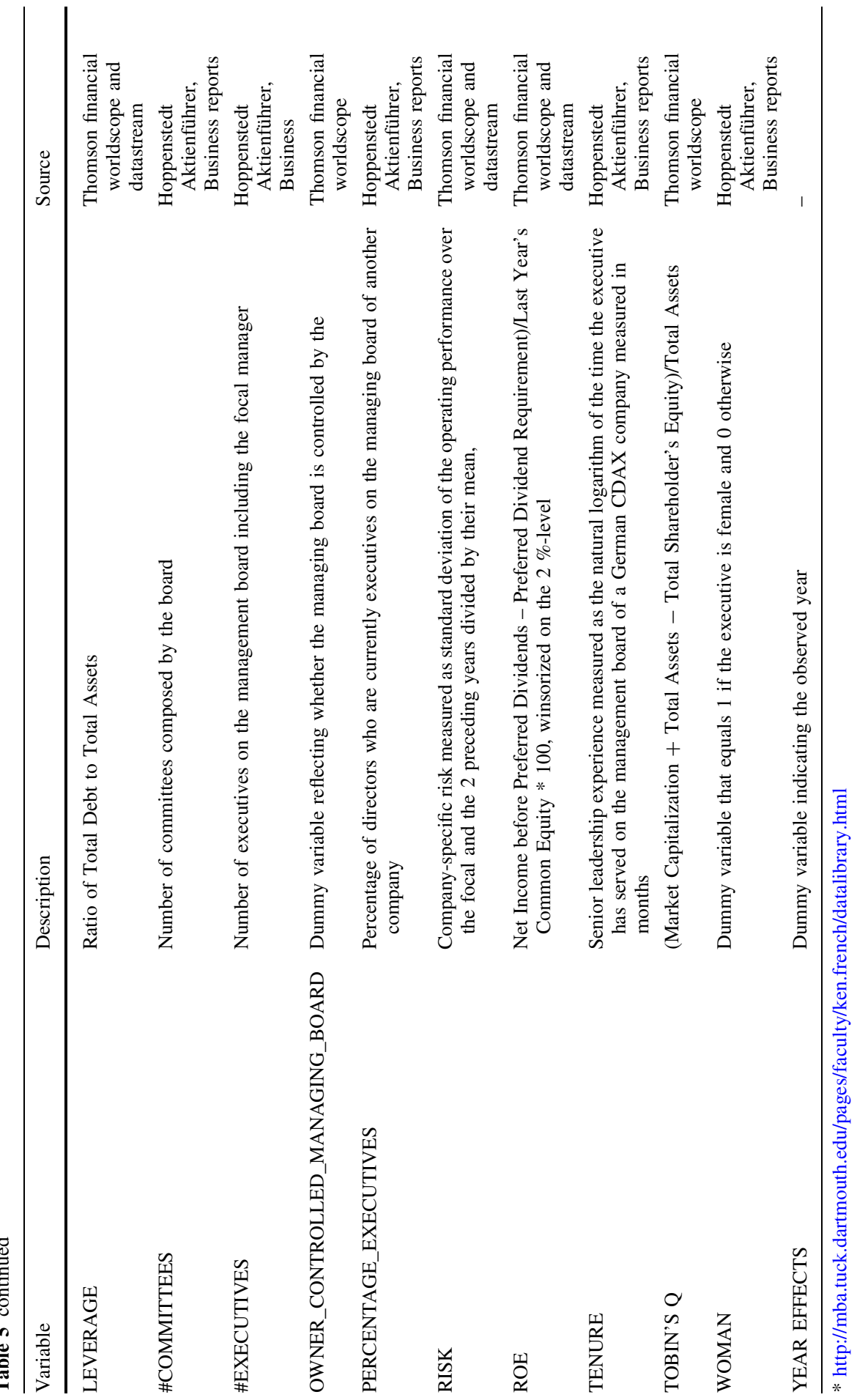




\section{Executive summary}

Our study examines the differences in the level of compensation between female and male executives - the so-called gender pay gap-and how it is affected by the density of the directors' network that is created when directors serve on multiple boards. The empirical investigation is based on a matched sample of 112 executive year observations. Our results are twofold: We find that differences in managerial compensation between women and men still exist even if we take into account the possible explanations at the company level (financial, company and corporate governance characteristics) as well as at the personal level (age, tenure, functional responsibility). Female managers, thus, earn less than comparable male colleagues. We attribute our findings to the preferences of directors - the actual deciders on executive compensation levels - and consider different pay levels as a form of indirect discrimination. Thus, we question the role of the social network that directors are embedded in. We find evidence that directors use their network as a knowledge source to reduce stereotypes which in turn decreases the gender pay gap. Summarized, more embedded directors decrease the gender pay gap among executives.

Our findings help companies in various ways: Previous studies have shown that knowledge and experience are important resources that help directors fulfill their tasks. We can add the reduction of discrimination to the benefits of embeddedness. Embedded directors become more knowledgeable and experienced using their network as learning platform. They base their decisions about appointments and compensation contracts less on stereotypes and in turn make suitable candidates more competitive offers. This increases the firms' chances of attaining and retaining capable and competent executives. Furthermore, the utilization of these embeddedness effects is possible on all hierarchical levels: Gained knowledge and experience might help reduce stereotypes about minority groups among the majority workers of a company. This effect could be reinforced by trainings or crossmentoring programs within companies.

\section{References}

Adams, Renée B., and Daniel Ferreira. 2009. Women in the boardroom and their impact on governance and performance. Journal of Financial Economics 94(2): 291-309.

Ahern, Kenneth R., and Amy K. Dittmar. 2012. The changing of the boards: The impact on firm valuation of mandated female board representation. The Quarterly Journal of Economics 127(1): 137-197.

Ahuja, Gautam, Francisco Polidoro Jr, and Will Mitchell. 2009. Structural homophily or social asymmetry? The formation of alliances by poorly embedded firms. Strategic Management Journal 30(9): 941-958.

Aiken, Leona S., and Stephen G. West. 1991. Multiple Regression: Testing and Interpreting Interactions. Thousand Oaks: SAGE Publications.

Alissa, Walid M (2009): Boards' Response to Shareholders' Dissatisfaction: The Case of Shareholders' Say on Pay in the UK, Working Paper, SSRN.

Allen, Michael P. 1974. The structure of interorganizational elite cooptation: Interlocking corporate directorates. American Sociological Review 39(3): 393-406. 
Antle, Rick, and Abbie Smith. 1986. An empirical investigation of the relative performance evaluation of corporate executives. Journal of Accounting Research 24(1): 1-39.

Arellano, Manuel, and Stephen Bond. 1991. Some tests of specification for panel data: Monte carlo evidence and an application to employment equations. The Review of Economic Studies 58(2): 277-297.

Arthaud-Day, Marne L., S. Trevis Certo, Catherine M. Dalton, and Dan R. Dalton. 2006. A changing of the guard: Executive and director turnover following corporate financial restatements. Academy of Management Journal 49(6): 1119-1136.

Arulampalam, Wiji, Alison L. Booth, and Mark L. Bryan. 2007. Is there a glass ceiling over Europe? Exploring the Gender Pay Gap across the Wage Distribution. Industrial and Labor Relations Review 60(2): 163-186.

Ashkanasy, Neal M., Charmine E. Hartel, and Catherine S. Daus. 2002. Diversity and emotion: The new frontiers in organizational behavior research. Journal of Management 28(3): 307-338.

Baranchuk, Nina, Glenn MacDonald, and Jun Yang. 2011. The economics of super managers. Review of Financial Studies 24(10): 3321-3368.

Bebchuk, Lucian A., and Jesse M. Fried. 2006. Pay without performance: Overview of the issues. Academy of Management Perspectives 20(1): 5-24.

Becker, Gary S. 1957. The Economics of Discrimination, First Edit. Chicago: The University of Chicago Press.

Beckman, Christine M., and Pamela R. Haunschild. 2002. Network learning: The effects of partners' heterogeneity of experience on corporate acquisitions. Administrative Science Quarterly 47(1): 92-124.

Bertrand, Marianne, and Kevin F. Hallock. 2001. The gender gap in top corporate jobs. Industrial and Labor Relations Review 55(1): 3-21.

Bielby, William T., and James N. Baron. 1986. Men and women at work: Sex segregation and statistical discrimination. American Journal of Sociology 91(4): 759-799.

Bilimoria, Diana, and Sandy K. Piderit. 1994. Board committee membership: Effects of sex-based bias. Academy of Management Journal 37(6): 1453-1477.

Bizjak, John, Michael Lemmon, and Ryan Whitby. 2009. Option backdating and board interlocks. The Review of Financial Studies 22(11): 4821-4847.

Blau, Francine D., and Lawrence M. Kahn. 1999. Analyzing the gender pay gap. Quarterly Review of Economics and Finance 39(5): 625-646.

Blau, Francine D., and Lawrence M. Kahn. 2001. Understanding international differences in the gender pay gap. Journal of Labor Economics 21(1): 106-144.

Blau, Francine D., and Lawrence M. Kahn. 2007. The gender pay gap: Have women gone as far as they can? Academy of Management Perspectives 21(1): 7-23.

Bøhren, Øyvind, and R. Øystein Strøm. 2010. Governance and politics: Regulating independence and diversity in the board room. Journal of Business Finance \& Accounting 37(9-10): 1281-1308.

Bonacich, Phillip. 1972. Factoring and weighting approaches to status scores and clique identification. Journal of Mathematical Sociology 2(1): 113-120.

Bonacich, Phillip. 1987. Power and centrality : A family of measures. American Journal of Sociology 92(5): 1170-1182.

Bonacich, Phillip, and Paulette Lloyd. 2001. Eigenvector-like measures of centrality for asymmetric relations. Social Networks 23(3): 191-201.

Bowles, Hannah R., Linda Babcock, and Lei Lai. 2007. Social incentives for gender differences in the propensity to initiate negotiations: Sometimes it does hurt to ask. Organizational Behavior and Human Decision Processes 103(1): 84-103.

Boyd, Brian. 1990. Corporate linkages and organizational environment: A test of the resource dependence model. Strategic Management Journal 11(6): 419-430.

Boyd, Brian K. 1994. Board control and CEO compensation. Strategic Management Journal 15(5): 335-344.

Brammer, Stephen, Andrew Millington, and Stephen Pavelin. 2009. Corporate reputation and women on the board. British Journal of Management 20(1): 17-29.

Brenner, Steffen, and Joachim Schwalbach. 2003. Management quality, firm size, and managerial compensation: A comparison between Germany and the UK. Schmalenbach Business Review 55(4): 280-293.

Cannella, Albert A., Donald R. Fraser, and D. Scott Lee. 1995. Firm failure and managerial labor markets evidence from texas banking. Journal of Financial Economics 38(2): 185-210. 
Carpenter, Mason A., and James D. Westphal. 2001. The strategic context of external network ties: Examining the impact of director appointments on board involvement in strategic decision making. Academy of Management Journal 44(4): 639-660.

Casciaro, Tiziana, and Mikolaj J. Piskorski. 2005. Power imbalance mutual dependence, and constraint absorption: A closer look at resource dependence theory. Administrative Science Quarterly 50(2): 167-199.

Chowdhury, Shamsud D., and Eric Z. Wang. 2009. Institutional activism types and CEO compensation: A time-series analysis of large canadian corporations. Journal of Management 35(1): 5-36.

Daily, Catherine M., S. Trevis Certo, and Dan R. Dalton. 1999. A decade of corporate women: Some progress in the boardroom, none in the executive suite. Strategic Management Journal 20(1): 93-99.

Davis, Gerald F. 1991. Agents without principles? The spread of the poison pill through the network intercorporate. Administrative Science Quarterly 36(4): 583-613.

Davis, Gerald F., and Henrich R. Greve. 1997. Corporate elite networks and governance changes in the 1980s. American Journal of Sociology 103(1): 1-37.

Daymont, Thomas N., and Paul J. Andrisani. 1984. Job preferences, college major, and the gender gap in earnings. Journal of Human Resources 19(3): 408-428.

Devers, Cynthia E., Albert A. Cannella, Gregory P. Reilly, and Michele E. Yoder. 2007. Executive compensation: A multidisciplinary review of recent developments. Journal of Management 33(6): 1016-1072.

Dreher, George F., Jeong-Yeon Lee, and Thomas A. Clerkin. 2011. Mobility and cash compensation: The moderating effects of gender, race, and executive search firms. Journal of Management 37(3): 651-681.

Duchon, Dennis, Stephen G. Green, and Thomas D. Taber. 1986. Vertical dyad linkage: A longitudinal assessment of antecedents, measures, and consequences. Journal of Applied Psychology 71(1): 56-60.

Dutton, Jane E., Susan J. Ashford, Katherine A. Lawrence, and Kathi Miner-Rubino. 2002. Red light, green light: Making sense of the organizational context for issue selling. Organization Science 13(4): 355-369.

Elston, Julie A., and Lawrence G. Goldberg. 2003. Executive compensation and agency costs in Germany. Journal of Banking and Finance 27(7): 1391-1410.

Fahlenbrach, Rüdiger. 2009. Shareholder rights, boards, and CEO compensation. Review of Finance 13(1): 81-113.

Fama, Eugene F., and Kenneth R. French. 1997. Industry costs of equity. Journal of Financial Economics 43(2): 153-193.

Farrell, Kathleen A., Geoffrey C. Friesen, and Philip L. Hersch. 2008. How do firms adjust director compensation? Journal of Corporate Finance 14(2): 153-162.

Finkelstein, Sydney, and Donald C. Hambrick. 1989. Chief executive compensation: A study of the intersection of markets and political processes. Strategic Management Journal 10(2): 121-134.

Fiss, Peer C. 2006. Social influence effects and managerial compensation evidence from Germany. Strategic Management Journal 27(11): 1013-1031.

Geletkanycz, Marta A., and Brian K. Boyd. 2011. CEO outside directorships and firm performance: A reconciliation of agency and embeddedness views. Academy of Management Journal 54(2): 335-352.

Goldman, Barry M., Barbara A. Gutek, Jordan H. Stein, and Kyle Lewis. 2006. Employment discrimination in organizations: Antecedents and consequences. Journal of Management 32(6): 786-830.

Greig, Fiona. 2008. Propensity to negotiate and career advancement : Evidence from an investment bank that women are on a "slow elevator". Negotiation Journal 24(4): 495-508.

Grove, Wayne A., Andrew Hussey, and Michael Jetter. 2011. The gender pay gap beyond human capital. Journal of Human Resources 46(4): 827-874.

Gulati, Ranjay, and James D. Westphal. 1999. Cooperative or controlling? The effects of CEO-board relations and the content of interlocks on the formation of joint ventures. Administrative Science Quarterly 44(3): 473-506.

Harris, Ira C., and Katsuhiko Shimizu. 2004. Too busy to serve? An examination of the influence of overboarded directors. Journal of Management Studies 41(5): 775-798.

Haunschild, Pamela R., and Christine M. Beckman. 1998. When do interlocks matter?: Alternate sources of information and interlock influence. Administrative Science Quarterly 43(4): 815-844. 
Hill, Charles W., and Phillip Phan. 1991. CEO tenure as a determinant of CEO pay. Academy of Management Journal 34(3): 707-717.

Hillier, David, Julio Pindado, Valdoceu De Queiroz, and Chabela De La Torre. 2011. The impact of country-level corporate governance on research and development. Journal of International Business Studies 42(1): 76-98.

Hillman, Amy J., Albert A. Cannella, and Ira C. Harris. 2002. Women and racial minorities in the boardroom: How do directors differ? Journal of Management 28(6): 747-763.

Hillman, Amy J., Albert A. Cannella, and Ramona L. Paetzold. 2000. The resource dependence role of corporate directors: Strategic adaptation of board composition in response to environmental change. Journal of Management Studies 37(2): 235-256.

Hillman, Amy J., and Thomas Dalziel. 2003. Boards of directors and firm performance: Integrating agency and resource dependence perspectives. Academy of Management Review 28(3): 383-396.

Hillman, Amy J., Christine Shropshire, and Albert A. Cannella. 2007. Organizational predictors of women on corporate boards. Academy of Management Journal 50(4): 941-952.

Hillman, Amy J., Michael C. Withers, and Brian J. Collins. 2009. Resource dependence theory: A review. Journal of Management 35(6): 1404-1427.

Hoel, Marit. 2008. The Quota Story: Five Years of Change in Norway. In Women on Corporate Boards of Directors: International Research and Practice, ed. Susan Vinnicombe, Val Singh, Ronald J. Burke, Diana Bilimoria, and Morten Huse, 79-87. Cheltenham: Edward Elgar Publishing.

Huse, Morten, Sabina Nielsen, and Inger M. Hagen. 2009. Women and employee-elected board members, and their contributions to board control tasks. Journal of Business Ethics 89(4): 581-597.

Ibarra, Herminia. 1992. Homophily and differential returns: Sex differences in network structure and access in an advertising firm. Administrative Science Quarterly 37(3): 422-447.

Kaman, Vicki S., and Charmine E. Hartel. 1994. Gender differences in anticipated pay negotiation strategies and outcomes. Journal of Business and Psychology 9(2): 183-197.

King, Eden B., Michelle R. Hebl, Jennifer M. George, and Sharon F. Matusik. 2010. Understanding tokenism: Antecedents and consequences of a psychological climate of gender inequity. Journal of Management 36(2): 482-510.

Kuhnen, C.M., and A. Niessen. 2012. Public opinion and executive compensation. Management Science 58(7): 1249-1272.

Kulich, Clara, Grzegorz Trojanowski, Michelle K. Ryan, S. Alexander Haslam, and Luc Renneboog. 2011. Who gets the carrot and who gets the stick? Evidence of gender disparities in executive remuneration. Strategic Management Journal 32(3): 301-321.

Kulik, Carol T., and Mara Olekalns. 2012. Negotiating the gender divide: Lessons from the negotiation and organizational behavior literatures. Journal of Management 38(4): 1387-1415.

Lang, Kevin. 1986. A language theory of discrimination. The Quarterly Journal of Economics 101(2): 363-382.

Leuven, Edwin, and Barbara Sianesi (2003): PSMATCH2: Stata Module to Perform Full Mahalanobis and Propensity Score Matching, Common Support Graphing, and Covariate Imbalance Testing, Software http://ideas.repec.org/c/boc/bocode/s432001.html.

Lindstädt, Hagen, Kerstin Fehre, and Michael Wolff (2011): Frauen in Führungspositionen: Entgeltunterschiede bei Vorständen, Projektbericht: http://www.bmfsfj.de/BMFSFJ/Service/publikationen, $\operatorname{did}=185344$. html.

Lynall, Matthew D., Brian R. Golden, and Amy J. Hillman. 2003. Board composition from adolescence to maturity: A multitheoretic view. Academy of Management Review 28(3): 416-431.

Major, Brenda, and Ellen Konar. 1984. An investigation of sex differences in pay expectations and their possible causes. Academy of Management Journal 27(4): 777-792.

Masulis, Ronald W., and Shawn Mobbs (2012): Independent Director Incentives: Where Do Talented Directors Spend Their Time and Energy?, Working Paper, SSRN.

McPherson, Miller, and Lynn Smith-Lovin. 1987. Homophily in voluntary organizations: Status distance and the composition of face-to-face groups. American Sociological Review 52(3): 370-379.

McPherson, Miller, Lynn Smith-Lovin, and James M. Cook. 2001. Birds of a feather: Homophily in social networks. Annual Review of Sociology 27(1): 415-444.

Mills, C.Wright. 1956. The Power Elite. New York: Oxford University Press.

Millsap, Roger E., and Ross Taylor. 1996. Latent variable models in the investigation of salary discrimination: Theory and practice. Journal of Management 22(4): 653-673.

Musteen, Martina, Deepak K. Datta, and Benedict Kemmerer. 2010. Corporate reputation: Do board characteristics matter? British Journal of Management 21(2): 498-510. 
Niederle, Muriel, and Lise Vesterlund. 2007. Do women shy away from competition? Do men compete too much? The Quarterly Journal of Economics 122(3): 1067-1101.

O'Reilly, I.I.I., A. Charles, Brian G. Main, and Graef S. Crystal. 1988. CEO compensation as tournament and social comparison: A tale of two theories. Administrative Science Quarterly 33(2): 257-274.

Pathan, Shams. 2009. Strong boards, CEO power and bank risk-taking. Journal of Banking and Finance 33(7): 1340-1350.

Pearce, Jone L., and Qiumei J. Xu. 2012. Rating performance or contesting status: Evidence against the homophily explanation for supervisor demographic skew in performance ratings. Organization Science 22(3): 373-385.

Petersen, Mitchell A. 2009. Estimating standard errors in finance panel data sets: Comparing approaches. The Review of Financial Studies 22(1): 435-480.

Piderit, Sandy K., and Susan J. Ashford. 2003. Breaking silence: Tactical choices women managers make in speaking up about gender-equity issues. Journal of Management Studies 40(6): 1477-1502.

Plaks, Jason E., and E. Tory Higgins. 2000. Pragmatic use of stereotyping in teamwork: Social loafing and compensation as a function of inferred partner-situation fit. Journal of Personality and Social Psychology 79(6): 962-974.

Rapp, Marc S., and Michael Wolff. 2010. Determinanten Der Vorstandsvergütung-Eine Empirische Untersuchung Der Deutschen Prime-Standard-Unternehmen. Zeitschrift Für Betriebswirtschaft 80(10): 1075-1112.

Renneboog, Luc, and Yang Zhao. 2011. Us knows us in the UK: On director networks and CEO compensation. Journal of Corporate Finance 17(4): 1132-1157.

Renner, Celia, Janet M. Rives, and William F. Bowlin. 2002. The significance of gender in explaining senior executive pay variations: An exploratory study. Journal of Managerial Issues 14(3): 331-345.

Rosenbaum, Paul R., and Donald B. Rubin. 1983. The central role of the propensity score in observational studies for causal effects. Biometrika 70(1): 41-55.

Rubery, Jill. 1995. Performance-related pay and the prospects for gender pay equity. Journal of Management Studies 32(5): 637-654.

Santaló, Juan, and Carl J. Kock. 2009. Division director versus CEO compensation: New insights into the determinants of executive pay. Journal of Management 35(4): 1047-1077.

Shaw, Kenneth W., and May H. Zhang. 2010. Is CEO cash compensation punished for poor firm performance? The Accounting Review 85(3): 1065-1093.

Shipilov, Andrew V., Henrich R. Greve, and Timothy J. Rowley. 2010. When do interlocks matter? Institutional logics and the diffusion of multiple corporate governance practices. Academy of Management Journal 53(4): 846-864.

Shipilov, Andrew V., and Stan X. Li. 2008. Can you have your cake and eat it too? Structural holes' influence on status accumulation and market performance in collaborative networks. Administrative Science Quarterly 53(1): 73-108.

Shipilov, Andrew V., Stan X. Li, and Henrich R. Greve. 2011. The prince and the pauper: Search and brokerage in the initiation of status-heterophilous ties. Organization Science 22(6): 1418-1434.

Shropshire, Christine. 2010. The role of the interlocking director and board receptivity in the diffusion of practices. Academy of Management Review 35(2): 246-264.

Singh, Val, and Susan Vinnicombe. 2004. Why so few women directors in top UK boardrooms? Evidence and theoretical explanations. Corporate Governance: An International Review 12(4): 479-488.

Solberg, Eric, and Teresa Laughlin. 1995. The gender pay gap, fringe benefits, and occupational crowding. Industrial and Labor Relations Review 48(4): 692.

Tang, Jianyun, Mary Crossan, and W. Glenn Rowe. 2011. Dominant CEO, deviant strategy, and extreme performance: The moderating role of a powerful board. Journal of Management Studies 48(7): 1479-1503.

Tharenou, Phyllis. 2008. Disruptive decisions to leave home: Gender and family differences in expatriation choices. Organizational Behavior and Human Decision Processes 105(2): 183-200.

Thomsen, Steen, and Torben Pedersen. 2000. Ownership structure and economic performance in the largest European companies. Strategic Management Journal 21(6): 689-705.

Useem, Michael. 1982. Classwide rationality in the politics of managers and directors of large corporations in the United States and Great Britain. Administrative Science Quarterly 27(2): 199-226.

Vieito, João P., and Walayet A. Khan. 2012. Executive compensation and gender: S\&P 1500 listed firms. Journal of Economics and Finance 36(2): 371-399. 
Wellman, Beth. 1926. The school child's choice of companions. The Journal of Educational Research 14(2): 126-132.

Westphal, James D., and Poonam Khanna. 2003. Keeping directors in line: Social distancing as a control mechanism in the corporate elite. Administrative Science Quarterly 48(3): 361-398.

Westphal, James D., and Ithai Stern. 2007. Flattery will get you everywhere (especially if you are a male Caucasian): How ingratiation, boardroom behavior, and demographic minority status affect additional board appointments at US companies. Academy of Management Journal 50(2): 267-288.

Westphal, James D., and Edward J. Zajac. 1995. Who shall govern? CEO/board power, demographic similarity, and new director selection. Administrative Science Quarterly 40(1): 60-83.

White, Halbert. 1980. A heteroskedasticity-consistent covariance matrix estimator and a direct test for heteroskedasticity. Econometrica 48(4): 817-838.

Zona, Fabio, Alessandro Zattoni, and Alessandro Minichilli. 2013. A contingency model of boards of directors and firm innovation: The moderating role of firm size. British Journal of Management 24(3): 299-315. 